\title{
Kainate Receptors Are the Key to Understanding Synaptic Plasticity, Learning and Memory (Review)
}

\author{
DOI: 10.17691/stm2017.9.4.28
}

Received June 8, 2017

A.V. Popov, PhD, Researcher, Laboratory of Extrasynaptic Transmission, Institute of Neuroscience';

L.A. Kushnireva, Student, Faculty of Biology2;

M.S. Doronin, Junior Researcher, Laboratory of Extrasynaptic Transmission, Institute of Neuroscience";

J.M. Henley, Professor of Molecular Neuroscience ${ }^{3}$

1 Lobachevsky State University of Nizhni Novgorod, 23 Prospekt Gagarina, Nizhny Novgorod, 603950,

Russian Federation,

${ }^{2}$ Perm State National Research University, 15 Bukireva St., Perm, 614990, Russian Federation;

${ }^{3}$ School of Biochemistry, Centre for Synaptic Plasticity, Biomedical Sciences Building,

University of Bristol, Bristol, BS8 1TD, United Kingdom

Glutamatergic signaling is one of the main types of excitatory synaptic transmission in the brain. It plays a key role in the normal brain function and the cognitive performance. Glutamatergic signaling failure is associated with brain disorders; therefore this system is considered an essential target of therapeutic interventions. Glutamatergic synaptic transmission is mediated by a set of ionotropic and metabotropic glutamate receptors including the kainate receptors. These receptors (both ionotropic and metabotropic) are involved in the process of synaptic transmission by modulating the excitation/inhibition balance. The modulatory effect of kainate receptors is mediated by the mechanisms that involve the presynaptic and postsynaptic endings, the rhythmic activity of the neural network, the function of the astroglial network, and the neuron-glial interaction. Thus, a dysfunction of kainate receptors can lead to deviations in the balance between excitation and inhibition, disorders of the neuronal networks, and even epileptiform manifestations. The present report reviews the major mechanisms of ionotropic and metabotropic activation of kainate receptors involved in the regulation of synaptic transmission, plasticity, learning and memory.

Key words: kainate receptors; synaptic transmission; metabotropic effect; G-proteins; long-term potentiation; brain rhythms; cognitive functions; epilepsy.

According to the current concept, there are three major groups of ionotropic glutamate receptors, named after their selective agonists NMDA (N-methylD-aspartate), AMPA (a-amino-3-hydroxy-5-methyl-4isoxazole propionic acid) and kainate (kainic acid), and three groups of metabotropic receptors (mGluR), associated with the G proteins (the GTPase family); these two types of glutamate receptors differ by their structure and mechanism of action. The ionotropic glutamate receptors mediate most of the excitatory transmission in the CNS and play a major role in the regulation of synaptic plasticity. The glutamatergic signaling is highly important for synaptic transmission, normal brain functioning, and cognitive performance; therefore, interruptions in the normal signaling process can manifest in clinical disorders. Studying the neurotransmission pathways mediated by glutamate receptors is one of the main research tasks of neurobiology today.

Kainate receptors are unique among the family of glutamate receptors: they represent both the classical ionotropic and the non-classical metabotropic functions.

The role of kainate receptors (KAR) is not known well enough as compared with the AMPA and NMDA receptors (AMPAR and NMDAR). A major reason for that is that in addition to ionotropic effects, the kainate receptors also have a metabotropic effect, which is not typical. Another problem is that both KAR and AMPAR show some overlapping sensitivity to most competitive antagonists such as CNQX and NBQX; in addition, a selective AMPA agonist can activate kainate receptors. Despite the fact that new selective agonists for KAR are being developed, not all of them have due affinities. This issue complicates studying the receptor functions at the full scale.

It is known that the long-term potentiation requires the activation of NMDA receptors and the increase in expression of AMPA receptors on the postsynaptic membrane surface and/or the increase in the dendritic spine size. However, there is also an independent NMDA receptor that employs the metabotropic signaling pathways and stimulates the AMPAR incorporation into the membrane; this one is activated by kainic acid - a KAR agonist.

A good object for studying the presynaptic functions of kainate receptors is the synapses of unmyelinated axons, called mossy fibers, formed by granular cells of

For contacts: Popov Alexandr V., e-mail: popov@neuro.nnov.ru 
the hippocampal dentate fascia, where a high level of expression of the receptor subunits is found. The kainate receptors participate in the neurotransmission between the cervical fascia cells and the pyramidal neurons of the hippocampal CA3 area, showing a positive response to the release of the neurotransmitter from the presynaptic terminal and thus depolarizing the axons. Most of the studies on the synapses of mossy fibers in the hippocampal CA3 area in vertebrates address the presynaptic kainate receptors; however, the postsynaptic functions of these receptors are less studied.

The KAR are expressed mostly in the CNS neuronal cells. Along with that, glial cells also show the presence of all subunits of this receptor (mRNA or proteins), often in co-expression with the AMPA receptor subunits. In astrocytes, the receptor subunits are located throughout the entire cell, whereas in oligodendrocytes, they are mainly limited to the soma. In this case, the glutamateinduced membrane current in oligodendrocytes is fully generated via the AMPA and kainate receptors in both cell culture and brain sections.

The modulating function of kainate receptors is based on the mechanisms involving the presynaptic and postsynaptic endings, the rhythmic activity of the neural network, the function of the astroglial network, and the neuron-glial interactions. Thus, a dysfunction of kainate receptors can distort the excitation/inhibition balance and provoke one or more CNS disorders including manifestations of epileptiform brain activity.

\section{Classification and functions of ionotropic glutamate receptors}

There are three main types of ionotropic glutamate receptors (iGluRs), named after selective agonists: NMDA, AMPA, and kainate [1]. These receptors mediate most of the excitatory neurotransmission throughout the CNS and play a major role in synaptic plasticity. Another type of receptors is represented by $\delta$ receptors; those are also part of the iGluRs group, since they share homologous fragments with the subunits of NMDAR, AMPAR, and KAR. Notably, they do not bind glutamate, and no specific endogenous ligands have been identified [2].

The AMPA receptors are tetrameric ion channels, which largely conduct $\mathrm{Na}^{+}$and $\mathrm{K}^{+}$ions; they can also be permeable to $\mathrm{Ca}^{2+}$, which depends on the combination of their subunits [3]. The NMDA receptors are tetrameric complexes that can serve both voltage-dependent and ligand-dependent ion channels [4]. The kainate receptors are composed from five subunits of GluK1-5 [5] that combine to form tetrameric ion channels, which are mainly permeable to $\mathrm{Na}^{+}$and $\mathrm{K}^{+}$[6].

In most cases, the permeability of KAR to $\mathrm{Ca}^{2+}$ is very low and depends on the composition of the given receptor complex; the specific combination of subunits determines the KAR function [7]. The KAR subunits are similar to the AMPAR and NMDAR subunits [8], but their presence in the CNS is more limited. The conductance of the KAR channel is similar to that of the AMPAR channel, which is about 20 ps, but the rise and decay of postsynaptic potentials generated by KAR are slower than those of AMPAR [9].

To activate KAR [10-12], kainic acid or domoic acid are needed; these two are strong high affinity agonists of KAR and AMPAR [13]. High concentrations of kainate cause recurrent continuing limbic seizures in rodents; their manifestations resemble those in human temporal lobe epilepsy [14]. Kainate provokes behavioral changes, mitochondrial dysfunction, neuron degeneration, and can eventually lead to death [11, 15]. This detrimental effect of kainate (a non-decomposable analogue of glutamate that is 30 times more toxic) is called excitotoxicity [15].

Kainic acid causes depolarization of virtually all types of brain neurons in mammals; this effect is mediated by the activation of KAR and AMPAR and depends on kainate concentration. The currents induced by high concentrations of kainic acid $(>100 \mu \mathrm{M})$ occur mainly through AMPAR, since these receptors populate the neuron membranes at a higher density than the kainate receptors [10]. Also, KAR and AMPAR show some overlapping sensitivity to most competitive antagonists, such as CNQX and NBQX [16]. In addition, AMPA the major AMPAR agonist - can activate various KAR [8]. For a long time, the lack of specific antibodies to different KAR subunits made it difficult to study the distribution of these receptors. Specific antisera against the KAR - GluK2, 3 and GluK5 subunits are now available, although not all of them show sufficient selectivity [8]. The low affinity GluK1-3 subunits with their low affinity for kainic acid can assemble with each other and form functional homomeric receptors. In contrast, the high affinity subunits of GluK4, 5 have to combine with GluK1-3 to become functional heteromeric receptors [16-18]. The GluK1 subunit is mainly expressed in the hippocampal and cortical interneurons, and the GluK2 subunit is largely present in pyramidal cells of the hippocampus, cerebellum and cortical pyramidal cells [19]. The GluK1 and GluK2 subunits undergo editing at the mRNA level. The replacement of glutamine with arginine (most frequent substitute) brings about an almost complete loss of $\mathrm{Ca}^{2+}$ permeability [20]. The GluK3 subunit is less common; it appears in the IV layer of the neocortex and in the dentate gyrus of the hippocampus [21]. GluK4 is mainly expressed in pyramidal neurons of the hippocampal CA3 area, the dentate gyrus, the neocortex and Purkinje cells, whereas GluK5 is abundant throughout the entire brain [22].

The kainate receptors play a role in fine tuning of the balance between excitation and inhibition in the CNS [12]. They participate in synaptic transmission both at presynaptic [23, 24] and post-synaptic sites $[25,26]$, modulating the excitatory and inhibitory synaptic transmission [27-29]. Despite their role in neurotransmission, inhibiting the kainate receptors (or 
genetically ablating one of the subunits) showed no changes in the brain activity comparable to those found under the AMPA receptor inhibition [30-32].

\section{Role of presynaptic kainate receptors in synaptic transmission}

Presynaptic KAR play a crucial role in regulating the process of neurotransmission [33-34]. Exogenous KAR agonists regulate the release of the neurotransmitter both in the excitatory and inhibitory synapses (in the biphasic regimen), depending on the type of the synapse and the concentration of the agonist [35-37]. They modulate neurotransmission between the granular cells of the dentate fascia and the pyramidal neurons of the hippocampal CA3 area. Granular neurons of the dentate fascia receive information from the neocortex and transmit it to the hippocampus through their axons mossy fibers. The bundles of these unmyelinated axons run along the layer of apical dendrites of pyramidal neurons of the CA3 area and form synaptic complexes on them [38]. These synaptic complexes are controlled by high affinity KAR that are activated by the release of glutamate from axons, so the presynaptic receptors can actively depolarize presynaptic boutons or axons, thus showing a positive response to the release of the neurotransmitter [39-42]. A similar effect can be caused by high-frequency stimulation $(25-100 \mathrm{~Hz})$ of moss fibers. This positive feedback mechanism, which leads to enhanced activation of KAR and release of glutamate does not depend on activation of NMDA receptors [43]. It has been shown that the presynaptic KAR on mossy fibers are permeable to $\mathrm{Ca}^{2+}$ and that the influx of $\mathrm{Ca}^{2+}$ through these receptors facilitates the release of glutamate from the presynaptic terminal and the release of $\mathrm{Ca}^{2+}$ from internal calcium stores [44]. The released glutamate binds to glutamate receptors on the postsynaptic membrane, initiating the release of $\mathrm{Mg}^{2+}$ and blocking NMDA receptors. The influx of $\mathrm{Ca}^{2+}$ through NMDAR channels initiates a chain of events that can lead to long-term potentiation [45]. However, the permeability of presynaptic $\mathrm{KAR}$ to $\mathrm{Ca}^{2+}$ has not been confirmed; besides, if the synaptic transmission is susceptible to blockade by KAR antagonists at low $\mathrm{Ca}^{2+}$ concentrations, then high concentrations of $\mathrm{Ca}^{2+}$ would overcome this block, indicating an alternative pathway for $\mathrm{Ca}^{2+}$ to enter the presynaptic bouton [43]. Similar $\mathrm{Ca}^{2+}$ dependence has been found for the kainate receptor-mediated regulation of the inhibitory synaptic transmission in the medial prefrontal cortex [46].

In the hippocampal CA1 area, presynaptic KAR, when activated by external glutamate or glutamate released from the Shaffer collaterals, facilitate the release of the CNS inhibitory mediator $y$-aminobutyric acid (GABA). The endogenous glutamate can boost the inhibitory postsynaptic currents (IPSC), whereas exogenous agonists can either facilitate or inhibit the transmission depending on their concentrations $[32,47]$. It has been shown that by depolarizing the interneurons with kainic acid, presynaptic KAR can increase the extracellular concentration of GABA. This is a secondary decrease in the GABAergic inhibition of pyramidal cells by the negative feedback mechanism [48-52].

The role of presynaptic receptors in the glutamatergic excitatory postsynaptic currents (EPSC) induced in the mossy fibers was also studied [29, 53, 54]. High concentrations of kainic acid suppress the synaptic transmission [55-57]. Low kainate concentrations, on the contrary, enhanced the synaptic transmission via both AMPAR and NMDAR [58]. The latter effect was blocked by KAR antagonists, which indicates that KAR participate in this bi-directional mechanism [59]. According to some data, kainic acid increases the frequency of spontaneous IPSC in pyramidal hippocampal cells [35, 50-52, 60-61], which is explained by depolarization of interneurons [35, 50,51] or increased axonal excitability [61]. Other studies, on the contrary, show a decrease in the amplitude of IPSC induced in the hippocampal pyramidal neurons [28, 61], which is challenged by other investigators $[61,62]$ who failed to observe such a decrease in IPSC [38].

Thus, studies of the interactions of synaptic-related cells (interneuron-interneuron and interneuron-pyramidal neuron/dentate fascia cell) in CA1, CA3 and the dentate gyrus of the hippocampus showed that the effect of KAR activation on the inhibitory synaptic transmission depends on the type of pre- or post-synaptic cells, concentration of the agonist, synapse type, expression of subunits and receptor specificity [38].

\section{The non-classical metabotropic activation of kainate receptors}

It is known that the long-term potentiation requires the activation of NMDA receptors [63] and can include both the recirculation-dependent increase in the surface expression of AMPAR on the postsynaptic membrane and the increase in size of the dendritic spine [64]. However, there is also an NMDAR-independent mechanism that stimulates the incorporation of AMPA receptors $[65,66]$ into the membrane and is mediated by the metabotropic action of KAR in response to kainic acid. This mechanism of KAR signaling via G-proteins, in particular through the Go family and other secondary messengers, distinguish the KAR from the family of glutamate-directed ion channels [67]. This signaling mechanism is not well studied because KAR have a typical topology of ligand-dependent ion channels that do not contain normal motifs on C-terminal domains that would support direct binding to $G$ proteins. This may indicate the existence of additional intermediary proteins acting within the receptor-G protein signaling complex [9]. This non-classical pathway involves the activation of protein kinase $\mathrm{C}$ and phospholipase $\mathrm{C}$, which induce the NMDAR-independent hippocampal long-term potentiation, and cause structural changes (in 
size and shape) in neuronal spines of the hippocampal CA1 region [65]. There is also a KAR-mediated NMDARindependent long-term suppression, which can be caused by prolonged low-frequency stimulation or postsynaptic depolarization [66]. This kind of synaptic plasticity, independent of NMDAR activation, exists also in other areas of the CNS, which indicates the importance of such non-classical signaling. The above studies show that KAR have a variety of mechanisms for fine tuning of neuron activity; therefore, more information on the physiological role of this metabotropic KAR signaling is necessary to better understand its role in the CNS [67-69].

\section{The role of postsynaptic kainate receptors in synaptic transmission}

Post-synaptic kainate receptors have been found in several locations of the CNS, including the hippocampus $[27,70]$, the spinal cord [71], the somatosensory cortex [72], the cerebellum [73], and the medial entorhinal cortex [74].

Studies on dissociated neuronal cultures demonstrate that the activation of postsynaptic kainate receptors stimulates the surface expression of receptors containing the GluK2 subunit [74], and also the development of filopodia as well as the axonal and dendritic growth [7577]. This occurs with the help of metabotropic signaling, which facilitates the recycling of KAR in the spines with the help of Rab11-dependent release of the recycling endosomes towards the head of the spine. These endosomes are tubular membrane structures associated with microtubules that mediate the recirculation in the dendritic spines [78, 79]; it is important to note that these membranes contain the small Rab11 protein from the GTPase family [80, 81]. This non-classical metabotropic pathway mediates a positive feedback system that leads to an increase in the surface-expressed postsynaptic KAR associated with GluK2; the latter exemplifies a previously unknown self-regulated pathway. This pathway provides additional flexibility to synaptic regulation and is likely to have important physiological and pathophysiological implications for controlling the neuron excitability and synaptic transmission. A shortterm exposure to kainic acid causes externalization of KAR, whereas a longer stimulation by kainate leads to endocytosis and receptor degradation [75, 82]. This bidirectional feedback system demonstrates an elegant mechanism of scaling, which increases the number of KAR on low-active synapses and decreases it on highly active synapses. Low or moderate activation of KAR increases endosomal recycling in the spine through the metabotropic pathway, which involves the activation of protein kinase C, G protein and Rab11 [74].

The metabotropic action of postsynaptic KAR also induces NMDA-independent long-term potentiation. This can occur due to increased activity of voltage-dependent calcium channels, the influx of extracellular $\mathrm{Ca}^{2+}$, which in turn stimulates a calcium release from the calcium depot [83, 84]. It is also known that the metabotropic effect of postsynaptic KAR increases the excitability of neurons by inhibiting hyperpolarization caused by potassium current in pyramidal cells of the CA1 region of the hippocampus [85].

The kainate receptors have a wide functional spectrum of postsynaptic generation of exciting internal currents in the hippocampus [86]. It has been shown that a short-term high-frequency stimulation of mossy fibers causes slow EPSC mediated by postsynaptic high affinity kainate receptors in CA3 neurons [87, 88]. Some researchers suggest that the GluK1 subunit can modulate these EPSC, since a GluK1 antagonist reduced these currents. Similar to the EPSC associated with presynaptic KAR, increased concentrations of kainic acid also led to a decrease in the amplitude of EPSC [85]. EPSC mediated by postsynaptic KAR were found in pyramidal and fast-specific cells in the second, third, and fifth layers of the rat motor cortex [89], thalamic cortical synapses, and pyramidal neurons of the fifth layer of the neocortex $[90,91]$.

\section{Kainate receptors and the astroglia function}

Immunohistochemical studies demonstrated the expression of all KAR subunits (mRNA or protein) in glial cells and their co-expression with subunits of the AMPA receptor [92-94]. The GluK1-3 and GluK5 subunits are present in $50 \%$ of astrocytes and $40 \%$ of oligodendrocytes. In astrocytes, the subunits are distributed throughout the cell body, whereas in oligodendrocytes they are mainly limited to the soma. It has been reported that the glutamate-induced membrane current in oligodendrocytes is generated totally by AMPA and kainate receptors, both in culture $[38,95,96]$ and in brain sections [97, 98]. In addition, the kainate receptors identified in oligodendrocytes can mediate glutamate excitotoxicity [99, 100]. Kainate receptors containing the GluK1 subunits are essential for the transmission of astroglia-neuron signals in the hippocampus, where glutamate released from the astroglia sends a signal to inhibitory neurons by activating the neuronal kainate receptors [101, 102]. This addition of glutamate sensors, expressed in the glial cell membranes, allows the glia to decipher the neuronal activity, synchronize and integrate the neuronal, neuron-glial and glia-glial interactions [103-105].

\section{Kainate receptors and the rhythmic activity of neural networks}

It is known that KAR can facilitate the synchronous rhythmic electrical activity. An example of this mechanism in the healthy brain is gamma-oscillations (20-80 Hz) in the hippocampal and neocortical networks, which play an important role in learning and memory. In brain disorders, epileptiform electrographic seizures 


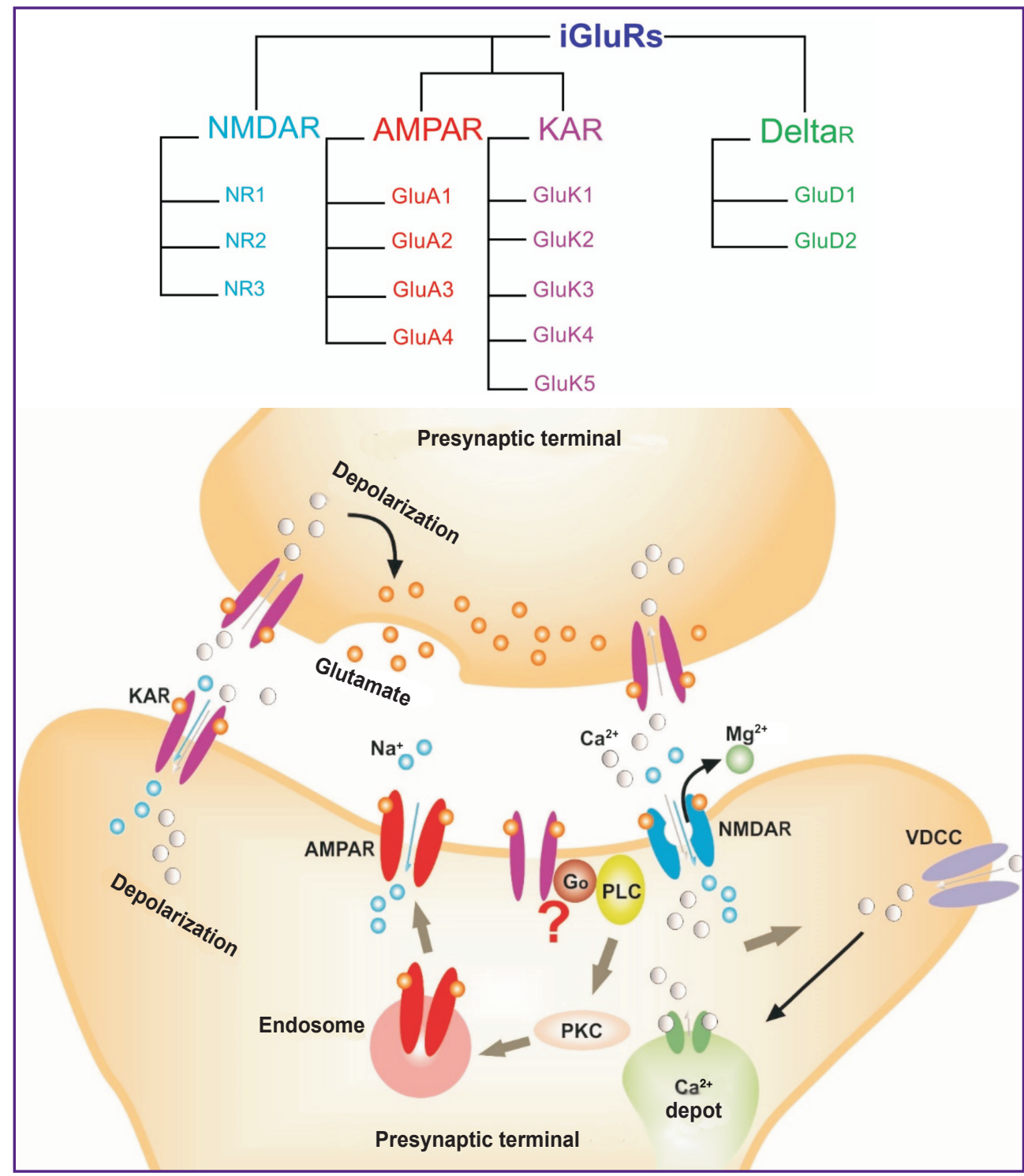

Family of ionotropic glutamate receptors with subunits (top); reactions involving the kainate receptors (bottom):

The influx of $\mathrm{Ca}^{2+}$ through KAR on the presynaptic terminal stimulates the release of glutamate into the synaptic cleft followed by its binding to the glutamate receptors on the postsynaptic membrane. This process initiates the release of $\mathrm{Mg}^{2+}$ that blocks the NMDA receptors and cause depolarization; the influx of $\mathrm{Ca}^{2+}$ through the NMDAR channels initiates a chain of events that can lead to long-term potentiation [45]. Here: PKC is protein kinase C; PLC - phospholipase C; VDCC — voltage-dependent calcium channel

(i.e. periodic high-frequency high-amplitude oscillations) can be observed. The induction of rhythmic activity by chemically activating the kainate receptors can generate stable gamma-oscillations [106, 107] independent of NMDAR, mGluRs or AMPAR [108]; kainate injections able to provoke epileptogenic bursts are used to model epileptogenesis in animals [109].

The GluK1 and GluK2 subunits play an important role in the generation of gamma-oscillations and epileptiform bursts; small changes in the overall activity in the hippocampal CA3 area can change the balance between excitation and inhibition, causing the neural network to switch from gamma-oscillations to epileptiform activity $[108,110]$. The absence of GluK1 or GluK2 subunits manifests in the phenotypes with gamma-oscillations. Thus, in the absence of GluK1, an increased susceptibility to epileptiform bursts develops whereas GluK2 ablation did not induce either gammaoscillations or epileptiform bursts. The results suggest that the GluK1 and GluK2 subunits play different roles in the rhythmic activity induced by kainate (see Figure) [110-113]. 


\section{Conclusion}

Kainate receptors differ from glutamate receptors as they have both ionotropic and metabotropic effects. They perform a number of important functions, such as mediation and modulation of synaptic transmission to maintain the balance of excitation and inhibition. The modulatory effect of kainate receptors is mediated by the mechanisms controlling the neuron activity and the function of glial cells. Kainate receptors are commonly expressed throughout the CNS, mainly in neurons, and also in glial cells. The kainate receptors act on both presynaptic and postsynaptic neuron endings, controlling the excitatory and inhibitory synaptic transmission and the glia function.

Presynaptic kainate receptors participate in controlling the release of inhibitory and excitatory neurotransmitters in the concentration-depending biphasic mode; the latter represents a homeostatic mechanism. These receptors act via several pathways to finely tune the neuron activity; these pathways include the non-classical metabotropic effect on synaptic transmission through G-proteins that induces the NMDAR-independent long-term potentiation. In addition, kainate receptors contribute to the morphological plasticity and expression in the dendritic spines of the GluK2-containing receptors. The glial cell receptor $s$ are sensitive to glutamate concentrations: excess glutamate triggers the release of neuroactive substances needed for the integration of neuronal activity and the mediation of glia-glial interactions. At the network level, the activation of kainate receptors is able to synchronize neurons, causing gamma-oscillations and/or epileptiform activity. Dysfunction of kainate receptors can lead to disturbances in the balance of excitation and inhibition and the development of pathological activity of neural networks. Thus, kainate receptors participate in the modulation of the rhythmic activity of neural networks, as well as in the neuron-glial interaction.

Compared with other glutamate receptors, such as AMPA and NMDA, the kainate receptors are less known in the literature but worth further research. Since the non-classical metabotropic signaling via kainate receptors is involved in the regulation of synaptic transmission, plasticity, learning and memory, it is especially important to study their morphological and functional aspects together with their physiological and pathological roles in the CNS. This will allow us to proceed to the study of a new class of pharmacological targets for the treatment of epilepsy and other CNS diseases. Therefore, studying the mechanisms mediated by the kainate receptors of glutamate is one of the main tasks of neurobiology today.

Financial Support. The study was supported by a grant from the Russian Science Foundation (project \#1614-00201).

Conflict of Interests. The authors have no conflict of interests.

\section{References}

1. Watkins J.C., Jane D.E. The glutamate story. $\mathrm{Br} J$ Pharmacol 2006; 147(Suppl 1): S100-S108, https://doi. org/10.1038/sj.bjp.0706444.

2. Lomeli H., Sprengel R., Laurie D.J., Köhr G., Herb A., Seeburg P.H., Wisden W. The rat delta-1 and delta-2 subunits extend the excitatory amino acid receptor family. FEBS Lett 1993; 315(3): 318-322, https://doi.org/10.1016/00145793(93)81186-4.

3. Gouaux E. Structure and function of AMPA receptors. $J$ Physiol 2004; 554(2): 249-253, https://doi.org/10.1113/ jphysiol.2003.054320.

4. Dingledine R., Borges K., Bowie D., Traynelis S.F. The glutamate receptor ion channels. Pharmacol Rev 1999; 51(1): 7-61.

5. Collingridge G.L., Olsen R.W., Peters J., Spedding M. A nomenclature for ligand-gated ion channels. Neuropharmacology 2009; 56(1): 2-5, https://doi.org/10.1016/j. neuropharm.2008.06.063.

6. Ferrer-Montiel A.V., Montal M. Pentameric subunit stoichiometry of a neuronal glutamate receptor. Proc Natl Acad Sci USA 1996; 93(7): 2741-2744, https://doi.org/10.1073/ pnas.93.7.2741

7. Atlason P.T., Scholefield C.L., Eaves R.J., MayoMartin M.B., Jane D.E., Molnár E. Mapping the ligand binding sites of kainate receptors: molecular determinants of subunit-selective binding of the antagonist [3H]UBP310. Mol Pharmacol 2010; 78(6): 1036-1045, https://doi.org/10.1124/ mol.110.067934.

8. Lerma J., Marques J.M. Kainate receptors in health and disease. Neuron 2013; 80(2): 292-311, https://doi. org/10.1016/j.neuron.2013.09.045.

9. Contractor A., Mulle C., Swanson G.T. Kainate receptors coming of age: milestones of two decades of research. Trends Neurosci 2011; 34(3): 154-163, https://doi. org/10.1016/j.tins.2010.12.002.

10. Nadler J.V. Kainic acid: neurophysiological and neurotoxic actions. Life Sci 1979; 24(4): 289-299, https://doi. org/10.1016/0024-3205(79)90325-4.

11. Ben-Ari Y. Limbic seizure and brain damage produced by kainic acid: Mechanisms and relevance to human temporal lobe epilepsy. Neuroscience 1985; 14(2): 375-403, https://doi. org/10.1016/0306-4522(85)90299-4.

12. Swanson G.T., Sakai R. Ligands for ionotropic glutamate receptors. Prog Mol Subcell Biol 2009; 46: 123-157, https://doi.org/10.1007/978-3-540-87895-7_5.

13. Hollmann M., Heinemann S. Cloned glutamate receptors. Annu Rev Neurosci 1994; 17(1): 31-108, https://doi. org/10.1146/annurev.ne.17.030194.000335.

14. Ben-Ari Y., Cossart R. Kainate, a double agent that generates seizures: two decades of progress. Trends Neurosci 2000; 23(11): 580-587, https://doi.org/10.1016/s01662236(00)01659-3.

15. Zhang X.M., Zhu J. Kainic acid-induced neurotoxicity: targeting glial responses and glia-derived cytokines. Curr Neuropharmacol 2011; 9(2): 388-398, https://doi. org/10.2174/157015911795596540.

16. Jane D.E., Lodge D., Collingridge G.L. Kainate receptors: pharmacology, function and therapeutic potential. Neuropharmacology 2009; 56(1): 90-113, https://doi. org/10.1016/j.neuropharm.2008.08.023.

17. Egebjerg J., Bettler B., Hermans-Borgmeyer I., 
Heinemann S. Cloning of a cDNA for a glutamate receptor subunit activated by kainate but not AMPA. Nature 1991; 351(6329): 745-748, https://doi.org/10.1038/351745a0.

18. Herb A., Burnashev N., Werner P., Sakmann B., Wisden W., Seeburg P.H. The KA-2 subunit of excitatory amino acid receptors shows widespread expression in brain and forms ion channels with distantly related subunits Neuron 1992; 8(4): 775-785, https://doi.org/10.1016/08966273(92)90098-x.

19. Ren Z., Riley N.J., Garcia E.P., Sanders J.M., Swanson G.T., Marshall J. Multiple trafficking signals regulate kainate receptor KA2 subunit surface expression. J Neurosci 2003; 23(16): 6608-6616.

20. Rozas J.L., Paternain A.V., Lerma J. Noncanonical signaling by ionotropic kainate receptors. Neuron 2003; 39(3): 543-553, https://doi.org/10.1016/s0896-6273(03)00436-7.

21. Köhler M., Burnashev N., Sakmann B., Seeburg P.H. Determinants of $\mathrm{Ca} 2+$ permeability in both TM1 and TM2 of high affinity kainate receptor channels: diversity by RNA editing. Neuron 1993; 10(3): 491-500, https://doi. org/10.1016/0896-6273(93)90336-p.

22. Wisden W., Seeburg P.H. A complex mosaic of highaffinity kainate receptors in rat brain. $J$ Neurosci 1993; 13(8): 3582-3598.

23. Bahn S., Volk B., Wisden W. Kainate receptor gene expression in the developing rat brain. $J$ Neurosci 1994; 14(9): $5525-5547$.

24. Lauri S.E., Delany C., J Clarke V.R., Bortolotto Z.A., Ornstein P.L., Isaac J.T.R., Collingridge G.L. Synaptic activation of a presynaptic kainate receptor facilitates AMPA receptor-mediated synaptic transmission at hippocampal mossy fibre synapses. Neuropharmacology 2001; 41(8): 907915, https://doi.org/10.1016/s0028-3908(01)00152-6.

25. Kullmann $M$. Presynaptic kainate receptors in the hippocampus: slowly emerging from obscurity. Neuron 2001; 32(4): 561-564, https://doi.org/10.1016/s0896-6273(01)00507-4.

26. Castillo P.E., Malenka R.C., Nicoll R.A. Kainate receptors mediate a slow postsynaptic current in hippocampal CA3 neurons. Nature 1997; 388(6638): 182-186, https://doi. org/10.1038/40645.

27. Vignes M., Collingridge G.L. The synaptic activation of kainate receptors. Nature 1997; 388(6638): 179-182, https:// doi.org/10.1038/40639.

28. Rodríguez-Moreno A., Herreras O., Lerma J. Kainate receptors presynaptically downregulate GABAergic inhibition in the rat hippocampus. Neuron 1997; 19(4): 893-901, https://doi. org/10.1016/s0896-6273(00)80970-8.

29. Contractor A., Swanson G.T., Sailer A., O'Gorman S., Heinemann S.F. Identification of the kainate receptor subunits underlying modulation of excitatory synaptic transmission in the CA3 region of the hippocampus. J Neurosci 2000; 20(22): 8269-8278.

30. Mulle C., Sailer A., Pérez-Otaño I., Dickinson-Anson H., Castillo P.E., Bureau I., Maron C., Gage F.H., Mann J.R., Bettler B., Heinemann S.F. Altered synaptic physiology and reduced susceptibility to kainate-induced seizures in GluR6deficient mice. Nature 1998; 392(6676): 601-605, https://doi. org/10.1038/33408.

31. Simmons R.M., Li D.L., Hoo K.H., Deverill M., Ornstein P.L., lyengar S. Kainate GluR5 receptor subtype mediates the nociceptive response to formalin in the rat. Neuropharmacology 1998; 37(1): 25-36, https://doi. org/10.1016/s0028-3908(97)00188-3.
32. Alt A., Weiss B., Ornstein P.L., Gleason S.D., Bleakman D., Stratford R.E. Jr., Witkin J.M. Anxiolytic-like effects through a GLUK5 kainate receptor mechanism. Neuropharmacology 2007; 52(7): 1482-1487, https://doi. org/10.1016/j.neuropharm.2007.02.005.

33. Pinheiro P.S., Mulle C. Presynaptic glutamate receptors: physiological functions and mechanisms of action. Nat Rev Neurosci 2008; 9(6): 423-436, https://doi.org/10.1038/ nrn2379.

34. Contractor A., Swanson G.T. Kainate receptors. In: Gereau R.W., Swanson G.T. (editors). The glutamate receptors. Humana Press; 2008; p. 99-158.

35. Jiang L., Xu J., Nedergaard M., Kang J. A kainate receptor increases the efficacy of GABAergic synapses. Neuron 2001; 30(2): 503-513.

36. Lerma J. Kainate receptor physiology. Curr Opin Pharmacol 2006; 6(1): 89-97, https://doi.org/10.1016/j. coph.2005.08.004.

37. Huettner J.E. Kainate receptors and synaptic transmission. Prog Neurobiol 2003; 70(5): 387-407, https://doi. org/10.1016/s0301-0082(03)00122-9.

38. Campbell S.L., Mathew S.S., Hablitz J.J. Pre- and postsynaptic effects of kainate on layer II/III pyramidal cells in rat neocortex. Neuropharmacology 2007; 53(1): 37-47, https:// doi.org/10.1016/j.neuropharm.2007.04.008.

39. Contractor A., Swanson G., Heinemann SF. Kainate receptors are involved in short- and long-term plasticity at mossy fiber synapses in the hippocampus. Neuron 2001; 29(1): 209-216, https://doi.org/10.1016/s08966273(01)00191-x.

40. Bortolotto Z.A., Clarke V.R., Delany C.M., Parry M.C., Smolders I., Vignes M., Ho K.H., Miu P., Brinton B.T., Fantaske R., Ogden A., Gates M., Ornstein P.L., Lodge D., Bleakman D., Collingridge G.L. Kainate receptors are involved in synaptic plasticity. Nature 1999; 402(6759): 297-301, https:// doi.org/10.1038/46290.

41. Lauri S.E., Bortolotto Z.A., Bleakman D., Ornstein P.L., Lodge D., Isaac J.T., Collingridge G.L. A critical role of a facilitatory presynaptic kainate receptor in mossy fiber LTP. Neuron 2001; 32(4): 697-709, https://doi.org/10.1016/s08966273(01)00511-6.

42. Schmitz D., Mellor J., Nicoll R.A. Presynaptic kainate receptor mediation of frequency facilitation at hippocampal mossy fiber synapses. Science 2001; 291(5510): 1972-1976, https://doi.org/10.1126/science.1057105.

43. Lauri S.E., Bortolotto Z.A., Nistico R., Bleakman D., Ornstein P.L., Lodge D., Isaac J.T., Collingridge G.L. A role for $\mathrm{Ca} 2+$ stores in kainate receptor-dependent synaptic facilitation and LTP at mossy fiber synapses in the hippocampus. Neuron 2003; 39(2): 327-341, https://doi.org/10.1016/s08966273(03)00369-6.

44. Scott R., Lalic T., Kullmann D.M., Capogna M., Rusakov D.A. Target-cell specificity of kainate autoreceptor and $\mathrm{Ca} 2+$-store dependent short-term plasticity at hippocampal mossy fiber synapses. J Neurosci 2008; 28(49): 13139-13149, https://doi.org/10.1523/jneurosci.2932-08.2008.

45. Voglis G., Tavernarakis N. The role of synaptic ion channels in synaptic plasticity. EMBO Rep 2006; 7(11): 11041110, https://doi.org/10.1038/sj.embor.7400830.

46. Mathew S.S., Pozzo-Miller L., Hablitz J.J. Kainate modulates presynaptic GABA release from two vesicle pools. J Neurosci 2008; 28(3): 725-731, https://doi.org/10.1523/ jneurosci.3625-07.2008 
47. Min M.Y., Melyan Z., Kullmann D.M. Synaptically released glutamate reduces gamma-aminobutyric acid (GABA) ergic inhibition in the hippocampus via kainate receptors. Proc Natl Acad Sci USA 1999; 96(17) 9932-9937, https://doi. org/10.1073/pnas.96.17.9932.

48. Kerchner G.A., Wang G.D., Quu C.S., Huettner J.E., Zhuo M. Direct presynaptic regulation of GABA/glycine release by kainate receptors in the dorsal horn: an ionotropic mechanism. Neuron 2001; 32(3): 477-488, https://doi. org/10.1016/s0896-6273(01)00479-2.

49. Frerking M., Petersen C.C., Nicoll R.A. Mechanisms underlying kainate receptor-mediated disinhibition in the hippocampus. Proc Natl Acad Sci USA 1999; 96(22): 1291712922, https://doi.org/10.1073/pnas.96.22.12917.

50. Cossart R., Esclapez M., Hirsch J.C., Bernard C., Ben-Ari Y. GluR5 kainate receptor activation in interneurons increases tonic inhibition of pyramidal cells. Nat Neurosci 1998; 1(6): 470-478, https://doi.org/10.1038/2185.

51. Frerking M., Malenka R.C., Nicoll R.A. Synaptic activation of kainate receptors on hippocampal interneurons. Nat Neurosci 1998; 1(6): 479-486, https://doi.org/10.1038/2194.

52. Semyanov A., Kullmann D.M. Kainate receptordependent axonal depolarization and action potential initiation in interneurons. Nat Neurosci 2001; 4(7): 718-723, https://doi. org/10.1038/89506.

53. Kamiya H., Ozawa S. Kainate receptor-mediated presynaptic inhibition at the mouse hippocampal mossy fibre synapse. J Physiol 2000; 523(Pt 3): 653-665, https://doi. org/10.1111/j.1469-7793.2000.t01-1-00653.x.

54. Schmitz D., Frerking M., Nicoll R.A. synaptic activation of presynaptic kainate receptors on hippocampal mossy fiber synapses. Neuron 2000; 27(2): 327-238, https://doi. org/10.1016/s0896-6273(00)00040-4.

55. Vignes M., Clarke V.R., Parry M.J., Bleakman D., Lodge D., Ornstein P.L., Collingridge G.L. The GluR5 subtype of kainate receptor regulates excitatory synaptic transmission in areas CA1 and CA3 of the rat hippocampus. Neuropharmacology 1998; 37(10-11): 1269-1277, https://doi. org/10.1016/s0028-3908(98)00148-8.

56. Chittajallu R., Vignes M., Dev K.K., Barnes J.M., Collingridge G.L., Henley J.M. Regulation of glutamate release by presynaptic kainate receptors in the hippocampus. Nature 1996; 379(6560): 78-81, https://doi.org/10.1038/379078a0.

57. Kamiya H., Ozawa S. Kainate receptor-mediated inhibition of presynaptic Ca2+ influx and EPSP in area CA1 of the rat hippocampus. J Physiol 1998; 509(Pt 3): 833-845, https://doi.org/10.1111/j.1469-7793.1998.833bm.x.

58. Kerchner G.A., Wilding T.J., Li P., Zhuo M., Huettner J.E. Presynaptic kainate receptors regulate spinal sensory transmission. J Neurosci 2001; 21(1): 59-66.

59. Rodríguez-Moreno A., Sihra T.S. Presynaptic kainate receptor-mediated facilitation of glutamate release involves Ca2+-calmodulin and PKA in cerebrocortical synaptosomes. FEBS Lett 2013; 587(6): 788-792, https://doi.org/10.1016/j. febslet.2013.01.071.

60. Fisahn A., Yamada M., Duttaroy A., Gan J.W., Deng C.X., McBain C.J., Wess J. Muscarinic induction of hippocampal gamma oscillations requires coupling of the $\mathrm{M} 1$ receptor to two mixed cation currents. Neuron 2002; 33(4): 615-624, https://doi.org/10.1016/s0896-6273(02)00587-1.

61. Maingret F., Lauri S.E., Taira T., Isaac J.T. Profound regulation of neonatal $\mathrm{CA} 1$ rat hippocampal GABAergic transmission by functionally distinct kainate receptor populations. J Physiol 2005; 567(Pt 1): 131-142, https://doi. org/10.1113/jphysiol.2005.089474.

62. Rodríguez-Moreno A., López-García J.C., Lerma J. Two populations of kainate receptors with separate signaling mechanisms in hippocampal interneurons. Proc Natl Acad Sci USA 2000; 97(3): 1293-1298, https://doi.org/10.1073/ pnas.97.3.1293.

63. Schmitz D., Mellor J., Frerking M., Nicoll R.A. Presynaptic kainate receptors at hippocampal mossy fiber synapses. Proc Natl Acad Sci USA 2001; 98(20): 1100311008, https://doi.org/10.1073/pnas.191351498.

64. Malenka R.C., Bear M.F. LTP and LTD: an embarrassment of riches. Neuron 2004; 44(1): 5-21, https:// doi.org/10.1016/j.neuron.2004.09.012.

65. Park M., Penick E.C., Edwards J.G., Kauer J.A., Ehlers M.D. Recycling endosomes supply AMPA receptors for LTP. Science 2004; 305(5692): 1972-1975, https://doi. org/10.1126/science.1102026.

66. Selak S., Paternain A.V., Aller M.I., Picó E., Rivera R., Lerma J. A role for SNAP25 in internalization of kainate receptors and synaptic plasticity. Neuron 2009; 63(3): 357371, https://doi.org/10.1016/j.neuron.2009.07.017.

67. Petrovic M.M., Viana da Silva S., Clement J.P., Vyklicky L., Mulle C., González-González I.M., Henley J.M. Metabotropic action of postsynaptic kainate receptors triggers hippocampal long-term potentiation. Nat Neurosci 2017; 20(4): 529-539, https://doi.org/10.1038/nn.4505.

68. Rodrigues R.J., Lerma J. Metabotropic signaling by kainate receptors. Wiley Interdisciplinary Reviews: Membrane Transport and Signaling 2012; 1(4): 399-410, https://doi. org/10.1002/wmts.35.

69. Nicoll R.A., Mellor J., Frerking M., Schmitz D. Kainate receptors and synaptic plasticity. Nature 2000; 406(6799): 957, https://doi.org/10.1038/35023075.

70. Li P., Wilding T.J., Kim S.J., Calejesan A.A., Huettner J.E., Zhuo M. Kainate-receptor-mediated sensory synaptic transmission in mammalian spinal cord. Nature 1999; 397(6715): 161-164, https://doi.org/10.1038/16469.

71. Kidd F.L., Isaac J.T. Developmental and activitydependent regulation of kainate receptors at thalamocortical synapses. Nature 1999; 400(6744): 569-573, https://doi. org/10.1038/23040.

72. Bureau I., Dieudonne S., Coussen F., Mulle C. Kainate receptor-mediated synaptic currents in cerebellar Golgi cells are not shaped by diffusion of glutamate. Proc Natl Acad Sci USA 2000; 97(12): 6838-6843, https://doi.org/10.1073/ pnas.97.12.6838.

73. West P.J., Dalpé-Charron A., Wilcox K.S. Differential contribution of kainate receptors to excitatory postsynaptic currents in superficial layer neurons of the rat medial entorhinal cortex. Neuroscience 2007; 146(3): 1000-1012, https://doi. org/10.1016/j.neuroscience.2007.02.035.

74. González-González I.M., Henley J.M. Postsynaptic kainate receptor recycling and surface expression are regulated by metabotropic autoreceptor signalling. Traffic 2013; 14(7): 810-822, https://doi.org/10.1111/tra.12071.

75. Tashiro A., Dunaevsky A., Blazeski R., Mason C.A., Yuste R. Bidirectional regulation of hippocampal mossy fiber filopodial motility by kainate receptors: a two-step model of synaptogenesis. Neuron 2003; 38(5): 773-784, https://doi. org/10.1016/s0896-6273(03)00299-x.

76. Martin S., Bouschet T., Jenkins E.L., Nishimune A., Henley J.M. Bidirectional regulation of kainate receptor 
surface expression in hippocampal neurons. J Biol Chem 2008; 283(52): 36435-36440, https://doi.org/10.1074/jbc. m806447200.

77. Suzuki F., Makiura Y., Guilhem D., Sørensen J.C., Onteniente B. Correlated axonal sprouting and dendritic spine formation during kainate-induced neuronal morphogenesis in the dentate gyrus of adult mice. Exp Neurol 1997; 145(1): 203213, https://doi.org/10.1006/exnr.1997.6469.

78. Prekeris R., Foletti D.L., Scheller R.H. Dynamics of tubulovesicular recycling endosomes in hippocampal neurons. J Neurosci 1999; 19(23): 10324-10337.

79. Cooney J.R., Hurlburt J.L., Selig D.K., Harris K.M., Fiala J.C. Endosomal compartments serve multiple hippocampal dendritic spines from a widespread rather than a local store of recycling membrane. J Neurosci 2002; 22(6): 2215-2224.

80. Stenmark H. Rab GTPases as coordinators of vesicle traffic. Nat Rev Mol Cell Biol 2009; 10(8): 513-525, https://doi. org/10.1038/nrm2728.

81. Hutagalung A.H., Novick P.J. Role of Rab GTPases in membrane traffic and cell physiology. Physiol Rev 2011; 91(1): 119-149, https://doi.org/10.1152/physrev.00059.2009.

82. Martin S., Henley J.M. Activity-dependent endocytic sorting of kainate receptors to recycling or degradation pathways. EMBO J 2004; 23(24): 4749-4759, https://doi. org/10.1038/sj.emboj.7600483.

83. Miyazaki K., Ross W.N. Ca2+ sparks and puffs are generated and interact in rat hippocampal CA1 pyramidal neuron dendrites. J Neurosci 2013; 33(45): 17777-17788, https://doi.org/10.1523/JNEUROSCI.2735-13.2013.

84. Rose C.R., Konnerth A. Stores not just for storage. Neuron 2001; 31(4): 519-522, https://doi.org/10.1016/s08966273(01)00402-0.

85. Melyan Z., Wheal H.V., Lancaster B. Metabotropicmediated kainate receptor regulation of IsAHP and excitability in pyramidal cells. Neuron 2002; 34(1): 107-114, https://doi. org/10.1016/s0896-6273(02)00624-4.

86. Bortolotto Z.A., Nistico R., More J.C., Jane D.E., Collingridge G.L. Kainate receptors and mossy fiber LTP. Neurotoxicology 2005; 26(5): 769-777, https://doi. org/10.1016/j.neuro.2005.02.004.

87. Li H., Rogawski M.A. GluR5 kainate receptor mediated synaptic transmission in rat basolateral amygdala in vitro. Neuropharmacology 1998; 37(10-11): 1279-1286, https://doi. org/10.1016/s0028-3908(98)00109-9.

88. Yeckel M.F., Kapur A., Johnston D. Multiple forms of LTP in hippocampal CA3 neurons use a common postsynaptic mechanism. Nat Neurosci 1999; 2(7): 625-633, http://dx.doi. org/10.1038/10180.

89. Ali A.B. Involvement of post-synaptic kainate receptors during synaptic transmission between unitary connections in rat neocortex. Eur J Neurosci 2003; 17(11): 2344-2350, https:// doi.org/10.1046/j.1460-9568.2003.02677.x.

90. Eder M., Becker K., Rammes G., Schierloh A., Azad S.C., Zieglgänsberger W., Dodt H.U. Distribution and properties of functional postsynaptic kainate receptors on neocortical layer V pyramidal neurons. J Neurosci 2003; 23(16): 6660-6670.

91. Beed P.S., Salmen B., Schmitz D. GluK2-mediated excitability within the superficial layers of the entorhinal cortex. PLoS One 2009; 4(5): e5576, https://doi.org/10.1371/journal. pone.0005576.

92. Brand-Schieber E., Lowery S.L., Werner P. Select ionotropic glutamate AMPA/kainate receptors are expressed at the astrocyte-vessel interface. Brain Res 2004; 1007(1-2): 178-182, https://doi.org/10.1016/j.brainres.2003.12.051.

93. Gutiérrez-Igarza K., Fogarty D.J., Pérez-Cerdá F, Doñate-Oliver F., Albus K., Matute C. Localization of AMPAselective glutamate receptor subunits in the adult cat visual cortex. Vis Neurosci 1996; 13(1): 61-72, https://doi. org/10.1017/s0952523800007136.

94. Vargas J.R., Takahashi D.K., Thomson K.E., Wilcox K.S. The expression of kainate receptor subunits in hippocampal astrocytes after experimentally induced status epilepticus. J Neuropathol Exp Neurol 2013; 72(10): 919-932, https://doi.org/10.1097/nen.0b013e3182a4b266.

95. Berger T., Walz W., Schnitzer J., Kettenmann H. GABAand glutamate-activated currents in glial cells of the mouse corpus callosum slice. J Neurosci Res 1992; 31(1): 21-27, https://doi.org/10.1002/jnr.490310104.

96. García-Barcina J.M., Matute C. Expression of kainateselective glutamate receptor subunits in glial cells of the adult bovine white matter. Eur J Neurosci 1996; 8(11): 2379-2387, https://doi.org/10.1111/j.1460-9568.1996.tb01201.x.

97. Barres B.A., Koroshetz W.J., Swartz K.J., Chun L.L., Corey D.P. Ion channel expression by white matter glia: the O-2A glial progenitor cell. Neuron 1990; 4(4): 507-524, https:// doi.org/10.1016/0896-6273(90)90109-s.

98. Tekkök S.B., Faddis B.T., Goldberg M.P. AMPA/kainate receptors mediate axonal morphological disruption in hypoxic white matter. Neurosci Lett 2005; 382(3): 275-279, https://doi. org/10.1016/j.neulet.2005.03.054.

99. Borges K., Kettenmann H. Blockade of K+ channels induced by AMPA/kainate receptor activation in mouse oligodendrocyte precursor cells is mediated by $\mathrm{Na}+$ entry. J Neurosci Res 1995; 42(4): 579-593, https://doi.org/10.1002/ jnr.490420416.

100. Alberdi E., Sánchez-Gómez M.V., Matute C. Calcium and glial cell death. Cell Calcium 2005; 38(3-4): 417-425, https://doi.org/10.1016/j.ceca.2005.06.020.

101. Alberdi E., Sánchez-Gómez M.V., Torre I., Domercq M., Pérez-Samartín A., Pérez-Cerdá F., Matute C. Activation of kainate receptors sensitizes oligodendrocytes to complement attack. J Neurosci 2006; 26(12): 3220-3228, https://doi.org/10.1523/jneurosci.3780-05.2006.

102. Frerking M. When astrocytes signal, kainate receptors respond. Proc Natl Acad Sci USA 2004; 101(9): 2649-2650, https://doi.org/10.1073/pnas.0400474101.

103. Liu Q.S., Xu Q., Arcuino G., Kang J., Nedergaard M. Astrocyte-mediated activation of neuronal kainate receptors Proc Natl Acad Sci USA 2004; 101(9): 3172-3177, https://doi. org/10.1073/pnas.0306731101.

104. Verkhratsky A., Kirchhoff F. Glutamate-mediated neuronal-glial transmission. J Anat 2007; 210(6): 651-660, https://doi.org/10.1111/j.1469-7580.2007.00734.x.

105. Gallo V., Zhou J.M., McBain C.J., Wright P., Knutson P.L., Armstrong R.C. Oligodendrocyte progenitor cell proliferation and lineage progression are regulated by glutamate receptor-mediated K+ channel block. J Neurosci 1996; 16(8): 2659-2670.

106. Buhl E.H., Tamás G., Fisahn A. Cholinergic activation and tonic excitation induce persistent gamma oscillations in mouse somatosensory cortex in vitro. J Physiol 1998; 513(Pt 1): 117-126, https://doi.org/10.1111/j.1469-7793.1998.117by.x.

107. Hormuzdi S.G., Pais I., LeBeau F.E., Towers S.K., Rozov A., Buhl E.H., Whittington M.A., Monyer H. Impaired 
electrical signaling disrupts gamma frequency oscillations in connexin 36-deficient mice. Neuron 2001; 31(3): 487-495, https://doi.org/10.1016/s0896-6273(01)00387-7.

108. Fisahn A., Contractor A., Traub R.D., Buhl E.H., Heinemann S.F., McBain C.J. Distinct roles for the kainate receptor subunits GluR5 and GluR6 in kainate-induced hippocampal gamma oscillations. J Neurosci 2004; 24(43): 9658-9668, https://doi.org/10.1523/jneurosci.2973-04.2004.

109. Nadler J.V. Minireview. Kainic acid as a tool for the study of temporal lobe epilepsy. Life Sci 1981; 29(20): 20312042, https://doi.org/10.1016/0024-3205(81)90659-7.

110. Stanger H.L., Alford R., Jane D.E., Cunningham M.O. The role of containing kainate receptors in entorhinal cortex gamma frequency oscillations. Neural Plast 2008; 2008: 1-12. https://doi.org/10.1155/2008/401645.
111. Sander T., Hildmann T., Kretz R., Fürst R., Sailer U., Bauer G., Schmitz B., Beck-Mannagetta G., Wienker T.F., Janz D. Allelic association of juvenile absence epilepsy with a GluR5 kainate receptor gene (GRIK1) polymorphism. Am J Med Genet 1997; 4(74): 416-421, https://doi.org/10. 1002/(sici)1096-8628(19970725)74:4<416::aid-ajmg13> 3.0.co;2-I.

112. Khalilov I., Hirsch J., Cossart R., Ben-Ari Y. Paradoxical anti-epileptic effects of a GluR5 agonist of kainate receptors. J Neurophysiol 2002; 1(88): 523-527.

113. Izzi C., Barbon A., Kretz R., Sander T., Barlati S. Sequencing of the GRIK1 gene in patients with juvenile absence epilepsy does not reveal mutations affecting receptor structure. Am J Med Genet 2002; 3(114): 354-359, https://doi. org/10.1002/ajmg.10254. 